Kajian Malaysia, Vol. 37, No. 2, 2019, 147-171

\title{
KETAKUTAN TERHADAP JENAYAH DALAM KALANGAN PELAJAR UNIVERSITI DI MALAYSIA: ANALISIS TERHADAP FAKTOR PENYUMBANG
}

\section{FEAR OF CRIMES AMONG UNIVERSITY STUDENTS IN MALAYSIA: ANAL YSES OF CONTRIBUTING FACTORS}

\section{Farahah Rosni ${ }^{1}$, Wan Shahrazad Wan Sulaiman² dan Mohammad Rahim Kamaluddin $^{2 *}$}

${ }^{1}$ Fakulti Sains Sosial dan Kemanusiaan, Universiti Kebangsaan Malaysia, Selangor, MALAYSIA

${ }^{2}$ Pusat Penyelidikan Psikologi dan Kesejahteraan Manusia, Universiti Kebangsaan Malaysia, Selangor, MALAYSIA

"Corresponding author: rahimk@ukm.edu.my

Published online: 20 November 2019

To cite this article: Farahah Rosni, Wan Shahrazad Wan Sulaiman and Mohammad Rahim Kamaluddin. 2019. Ketakutan terhadap jenayah dalam kalangan pelajar universiti di Malaysia: Analisis terhadap faktor penyumbang. Kajian Malaysia 37(2): 147-171. https://doi.org/10.21315/ $\mathrm{km} 2019.37 .2 .7$

To link to this article: https://doi.org/10.21315/km2019.37.2.7

\begin{abstract}
ABSTRAK
Ketakutan terhadap jenayah yang muncul menjadi isu yang membimbangkan dan dianggap masalah sosial kerana ia memberikan kesan yang negatif kepada kesejahteraan mental dan fizikal seseorang individu. Walaupun topik ini mendapat perhatian daripada penyelidik-penyelidik Barat sejak tahun 1960-an, namun masih tidak banyak kajian tentang ketakutan terhadap jenayah yang dijalankan di Malaysia. Tambahan pula, corak statistik jenayah di Malaysia yang tidak stabil dan persepsi rakyat Malaysia bahawa indeks jenayah semakin meningkat pada saban hari menjadikan isu ini wajar untuk dikaji. Oleh itu, objektif kajian ini adalah untuk menganalisis faktor penyumbang ketakutan terhadap jenayah dengan mengkaji faktor jantina, kawasan tempat tinggal dan sejarah menjadi mangsa jenayah terhadap tahap ketakutan, tahap keselamatan, persepsi risiko menjadi mangsa dan tingkah laku berjaga-jaga. Kajian ini dijalankan di beberapa universiti di Malaysia dengan menggunakan kaedah tinjauan melalui borang soal selidik yang diadaptasi daripada Fear of Crime in America Survey terhadap 303 orang pelajar universiti prasiswazah berwarganegara Malaysia. Hasil kajian ini
\end{abstract}

(C) Penerbit Universiti Sains Malaysia, 2019. This work is licensed under the terms of the Creative Commons Attribution (CC BY) (http://creativecommons.org/licenses/by/4.0/). 
mendapati bahawa pelajar perempuan mempunyai tahap ketakutan yang lebih tinggi dan kerap mengamalkan tingkah laku berjaga-jaga berbanding pelajar lelaki. Pelajar dari bandar dan luar bandar mempunyai tahap ketakutan, tahap keselamatan, dan persepsi risiko menjadi mangsa yang hampir sama, namun, pelajar dari bandar lebih banyak mengamalkan tingkah laku berjaga-jaga berbanding pelajar dari luar bandar. Kajian ini juga mendapati bahawa tiada perbezaan tahap ketakutan, tahap keselamatan dan persepsi risiko antara pelajar yang pernah menjadi mangsa dengan tidak pernah langsung menjadi mangsa. Hasil kajian ini telah memberikan idea untuk mengkaji isu ketakutan terhadap jenayah di Malaysia dengan lebih mendalam dan dari pelbagai aspek pada masa akan datang.

Kata kunci: keselamatan, ketakutan terhadap jenayah, pelajar universiti, persepsi risiko, tingkah laku berjaga-jaga

\begin{abstract}
Fear of crime has emerged as an issue of concern and perceived as a social problem since it leads to negative effects towards mental and physical wellbeing of an individual. Although this topic has received attention from Western researchers since the mid-1960s, however, not many researches were done on fear of crime in Malaysia. Furthermore, because of the fluctuating nature of crime statistics in the country, together with the perceptions that crime is increasing on a daily basis, this issue is worth researching. Therefore, the objective of this study is to analyse the contributing factors of fear of crime according to gender, types of residential areas, and victimisation effect on the level of fear, level of security, perceived risk of becoming a victim and precautionary behaviours. This study was conducted in a few universities in Malaysia by using a survey method through questionnaires adopted from the Fear of Crime in America Survey that was given to 303 undergraduate Malaysian students. This study shows that female students exhibit a higher level of fear and often adopt precautionary behaviours compared to male students. Students from rural and town areas had a similar level offear, level of security, perception of risk of becoming a victim, however, students from the town areas used precautionary behaviours more often than students from the rural areas. The study also found no differences in the level of fear, level of security and risk perception among students who had been victimised and who had not been one. This study has provided an insight for more diverse and profound future researches on the issue of fear of crime in Malaysia.
\end{abstract}

Keywords: crime, safety, fear of crime, university students, perception of risk, precautionary behaviours 


\section{PENGENALAN}

Ketakutan terhadap jenayah muncul menjadi isu yang membimbangkan pada sekitar pertengahan tahun 1960 apabila satu kajian nasional tentang persepsi terhadap jenayah dijalankan di Amerika Syarikat (Hacin dan Eman 2014). Hasil kajian tersebut yang telah diterbitkan dalam laporan "The Challenge of Crime in a Free Society" mendapati bahawa ketakutan terhadap jenayah menurunkan kualiti hidup kebanyakan warga Amerika Syarikat. Laporan itu juga menunjukkan bahawa ketakutan terhadap jenayah didapati berbeza mengikut jantina, bangsa, pendapatan, dan pengalaman menjadi mangsa dalam kalangan masyarakat Amerika Syarikat.

Ketakutan terhadap jenayah menjadi tumpuan kebanyakan negara kerana hal ini menjadi satu barometer dalam menentukan keamanan dan juga keselamatan sesebuah negara. Banyak cara dan kaedah yang digunakan untuk mengukur ketakutan terhadap jenayah dalam kalangan masyarakat. Hal ini termasuklah pengukuran dengan menggunakan kaedah tinjauan melalui soal selidik dan juga kaedah temu bual dalam kalangan masyarakat awam. Tidak dapat dinafikan bahawa laporan yang dihasilkan melalui kajian-kajian tentang ketakutan terhadap jenayah sering mendapat perhatian masyarakat awam dan juga pihak media.

\section{PERMASALAHAN KAJIAN}

Di Malaysia, indeks jenayah mula menunjukkan penurunan sebanyak $40 \%$ sejak tahun 2009 (Unit Pengurusan Prestasi dan Pelaksanaan [PEMANDU] 2015) dengan penurunan kes jenayah kekerasan daripada 42,365 insiden pada tahun 2009 kepada 29,375 insiden pada tahun 2013 (Muhammad Amin, Mohammad Rahim dan Geshina Ayu 2014). Namun begitu, apabila Frost dan Sullivan melakukan tinjauan di Malaysia mengenai pendapat orang awam tentang tahap jenayah sejak tiga tahun yang lalu, 50\% daripada responden berpendapat indeks jenayah semakin meningkat, $40 \%$ beranggapan indeks jenayah adalah tetap sepanjang tiga tahun yang lalu dan hanya $10 \%$ daripada orang awam berasakan indeks jenayah telah menurun (Amin Khan 2015).

Chadee, Austin dan Ditton (2007) menegaskan bahawa ketakutan terhadap jenayah perlu dikaji mengikut jenisnya, iaitu ketakutan afektif dan ketakutan kognitif. Ketakutan afektif adalah respons emosi terhadap jenayah dan ancaman, manakala, ketakutan kognitif ialah persepsi risiko menjadi mangsa. Rader (2004) menambah satu lagi komponen ketakutan, iaitu ketakutan konatif yang melibatkan tingkah laku berjaga-jaga sebagai respons terhadap ketakutan terhadap jenayah. Menurutnya, ketakutan terhadap jenayah tidak sepatutnya dikaji tanpa dua fenomena ini, iaitu tingkah laku berjaga-jaga dan persepsi risiko menjadi mangsa. 
Namun begitu, komponen-komponen ini masih kurang diselidik di Malaysia apabila ketakutan terhadap jenayah dibincangkan.

Menurut Henson dan Reyns (2015), ciri-ciri demografi seperti jantina, umur, bangsa, kawasan tempat tinggal dan sejarah mangsa jenayah telah menjadi peramal yang penting dalam menerangkan ketakutan terhadap jenayah sejak lebih 40 tahun dahulu. Namun begitu, kajian-kajian lepas di Malaysia tentang ketakutan terhadap jenayah lebih banyak meneroka faktor persekitaran fizikal dan sosial berbanding faktor demografi, sejarah mangsa jenayah dan respons tingkah laku (Aldrin et al. 2015; Maruthaveeran dan Van de Bosh 2015; Siti Rasidah, Aldrin dan Mohd Najib 2013). Kajian ketakutan terhadap jenayah yang dilakukan dalam kalangan pelajar juga adalah terhad. Oleh itu, adalah mustahak untuk melihat tahap ketakutan terhadap jenayah rakyat Malaysia, khususnya dalam kalangan pelajar universiti mengikut faktor demografi.

\section{PERSOALAN KAJIAN}

Berdasarkan permasalahan kajian yang telah dibincangkan di atas, beberapa persoalan kajian telah diutarakan:

1. Apakah profil demografi dan sejarah mangsa jenayah dalam kalangan pelajar universiti di Malaysia?

2. Apakah tahap ketakutan terhadap jenayah, tahap keselamatan, tahap persepsi risiko menjadi mangsa dan tingkah laku berjaga-jaga dalam kalangan pelajar universiti di Malaysia?

3. Adakah terdapat perbezaan tahap ketakutan terhadap jenayah, tahap keselamatan, persepsi risiko menjadi mangsa dan tingkah laku berjaga-jaga mengikut faktor jantina, kawasan tempat tinggal dan sejarah mangsa jenayah dalam kalangan pelajar universiti di Malaysia?

\section{OBJEKTIF KAJIAN}

Berdasarkan permasalahan dan persoalan kajian yang dibincangkan di atas, kajian ini bertujuan untuk:

1. Menjana profil demografi dan mangsa jenayah dalam kalangan pelajar universiti di Malaysia; 
2. Mengenal pasti tahap ketakutan terhadap jenayah, tahap keselamatan, persepsi risiko menjadi mangsa, tingkah laku berjaga-jaga, dan profil sejarah mangsa jenayah dalam kalangan pelajar universiti di Malaysia; dan

3. Mengkaji perbezaan tahap ketakutan terhadap jenayah, tahap keselamatan, persepsi risiko menjadi mangsa; dan tingkah laku berjaga-jaga antara jantina, kawasan tempat tinggal dan sejarah mangsa jenayah dalam kalangan pelajar universiti di Malaysia.

\section{TINJAUAN LITERATUR}

Ketakutan terhadap jenayah dijelaskan sebagai reaksi emosi disebabkan bahaya yang dirasai dan kebimbangan berkait dengan persepsi bahaya (Garofalo 1981). Ketakutan terhadap jenayah boleh dilihat melalui tahap ketakutan, tahap keselamatan dan persepsi risiko menjadi mangsa. Terdapat tiga elemen yang sering diketengahkan apabila membincangkan fenomena ini, iaitu (1) faktor demografi seperti jantina, umur, bangsa, pendapatan dan pendidikan, (2) sejarah menjadi mangsa jenayah, dan (3) keadaan persekitaran fizikal dan sosial di kawasan kejiranan seperti kesan perbandaran, pencahayaan yang rendah, lorong jalan yang gelap atau terasing, vandalisme dan kepercayaan serta kohesi/jeleketan yang rendah antara jiran tetangga (Austin, Furr dan Spine 2002).

Banyak kajian mendapati wanita lebih cenderung melaporkan ketakutan terhadap jenayah yang tinggi dan tahap keselamatan yang rendah berbanding lelaki terutamanya terhadap jenayah kekerasan walaupun kurang kemungkinan menjadi mangsa dalam kebanyakan jenayah serius (Garofalo 1981; Hale 1996; Lee 2007; Rader dan Crossman 2011; Yirmibesoglu dan Ergun 2015). Cops, Pleysier dan Put (2012) mendapati bahawa serangan seksual menyebabkan wanita lebih takut kerana mereka mempersepsikan risiko menjadi mangsa untuk jenayah jenis ini adalah lebih tinggi daripada lelaki. Oleh itu, ancaman kemungkinan berlaku serangan seksual telah meningkatkan tahap ketakutan golongan wanita terhadap semua jenis jenayah (Rader dan Crossman 2011).

Terdapat kajian yang menunjukkan bangsa bukan berkulit putih berasa kurang selamat dan lebih tinggi tahap ketakutan berbanding bangsa berkulit putih (Boateng dan Adjekum-Boateng 2017; Crowl dan Battin 2016). Allen (2006) merumuskan data daripada British Crime Survey 2003 dan mendapati bahawa responden berlatar belakang Asia dan berkulit hitam mempunyai tahap ketakutan yang lebih tinggi terhadap jenayah rompak, samun dan jenayah kekerasan.

Kesan pemangsaan telah memainkan peranan penting dalam menjelaskan ketakutan terhadap jenayah. Mangsa jenayah secara langsung mempunyai tahap ketakutan terhadap jenayah yang lebih tinggi, tetapi ketakutan yang dialami 
hanyalah terhadap jenayah spesifik, iaitu jenayah yang melibatkan mangsa tersebut (Grinshteyn et al. 2016; Hanslmeir, Kemme dan Baier 2016). Namun begitu, individu yang pernah menyaksikan atau mendengar tentang keganasan atau jenayah (mangsa secara tidak langsung) juga mempunyai tahap ketakutan terhadap jenayah yang tinggi (Grinshteyn et al. 2016).

Ketakutan terhadap jenayah juga sering dikaitkan dengan kesan perbandaran. Individu yang tinggal di luar bandar mempunyai ketakutan yang lebih rendah dan penduduk bandar secara signifikan menunjukkan ketakutan yang lebih tinggi (Will 1995; Yarwood dan Gardner 2000). Tomsich, Gover dan Jennings (2011) mendapati bahawa pelajar yang menuntut di universiti di kawasan bandar menunjukkan persepsi risiko menjadi mangsa yang sederhana apabila berada di dalam kampus. Namun begitu, persepsi risiko menjadi mangsa meningkat dua kali ganda pada waktu malam berbanding waktu siang ketika berada di kampus. Agubokwu (2016) mendapati bahawa pelajar kolej di luar bandar adalah berbeza dengan pelajar kolej di bandar kerana pelajar kolej di bandar mempunyai persepsi risiko menjadi mangsa lebih tinggi daripada pelajar di kawasan luar bandar.

Ketakutan terhadap jenayah dianggap sebagai masalah sosial kerana ia memberikan kesan yang negatif terhadap kesejahteraan mental dan fizikal seperti kemurungan, kebimbangan, pengelakan (Pearson dan Breetzke 2013), kemerosoton hubungan kejiranan (Grinshteyn et al. 2016) dan membantutkan pembangunan ekonomi negara (Doran dan Burgess 2012). Selain itu, individu akan mengadaptasi tingkah laku berjaga-jaga untuk mengatasi ketakutan terhadap jenayah, iaitu tingkah laku pengelakan, tingkah laku mempertahankan diri, pelarasan tingkah laku dan gaya hidup, dan penyertaan dalam aktiviti kolektif (Ferraro 1995). Walaupun tingkah laku ini adalah penting untuk menghalang jenayah berlaku, tingkah laku ini juga mampu memberikan kesan sosial yang negatif sekiranya keterlaluan.

\section{METODOLOGI}

\section{Reka Bentuk dan Pengumpulan Data}

Penyelidikan yang dijalankan ini merupakan kajian kuantitatif menggunakan kaedah tinjauan yang bermatlamat untuk menganalisis perbezaan tahap ketakutan terhadap jenayah, tahap keselamatan, persepsi risiko menjadi mangsa dan tingkah laku berjaga-jaga mengikut faktor jantina, kawasan tempat tinggal dan sejarah mangsa jenayah. Menurut Mitchell dan Jolley (2013), kelebihan kaedah tinjauan menggunakan soal selidik adalah ia senang untuk disebarkan kepada orang ramai dan juga membenarkan kerahsiaan maklumat responden. Selain itu, kajian kuantitatif dengan menggunakan kaedah tinjauan juga membenarkan penyelidik untuk menguji hipotesis dan mengeneralisasikan dapatan kajian ke atas populasi yang dikaji. 
Sebelum soal selidik diedarkan kepada para responden, matlamat kajian serta isu-isu kerahsiaan data telah dijelaskan. Selain itu, para responden juga telah diberi taklimat tentang isu-isu etika dalam kajian ini. Antara isu etika yang ditekankan adalah anonimiti data, jangka masa pelupusan data serta penerbitan hasil kajian. Para responden juga telah diberitahu bahawa penyertaan adalah secara sukarela dan tidak ada sebarang paksaan. Setelah mendapat kebenaran bertulis daripada pihak responden, soal selidik telah diedarkan dalam bentuk kumpulan.

Para penyelidik bersama dengan pembantu penyelidik yang terlatih juga telah memastikan bahawa para responden telah memenuhi kriteria pemilihan sampel yang telah ditetapkan dalam kajian ini. Para responden direkrut dengan menggunakan kaedah persampelan rawak pelbagai. Secara purata, para responden telah mengambil masa selama 30 minit untuk menjawab kesemua item. Para penyelidik juga telah membuat semakan terakhir terhadap soal selidik sebelum dipungut untuk mengelakkan keciciran para responden. Para responden diucapkan terima kasih dan diberikan alat tulis sebagai honorarium.

\section{Responden}

Responden kajian terdiri daripada 303 pelajar prasiswazah berwarganegara Malaysia daripada beberapa universiti di Semenanjung Malaysia mewakili zon Utara, Selatan, Timur dan Barat (Jadual 1). Jumlah 303 ini merupakan bilangan yang diperlukan bagi membuat generalisasi dapatan kajian terhadap populasi pelajar universiti di Malaysia di mana pengiraan saiz sampel dibuat dengan mengambil kira jumlah populasi pelajar berserta kadar keyakinan kajian sebanyak $95 \%$.

Kriteria yang ditetapkan dalam kajian ini ialah responden haruslah seorang pelajar yang sedang menuntut di universiti di Semenanjung Malaysia, pelajar prasiswazah dan berwarganegara Malaysia. Para pelajar dari negara luar yang sedang mengikuti pengajian di Malaysia dan kurang fasih dalam bahasa Melayu dikecualikan dalam kajian ini.

Responden kajian ini adalah dalam lingkungan 20-an (22.17 \pm 1.49$)$. Seramai 46 responden ialah lelaki dan 257 responden perempuan. Sebanyak 84\% daripada responden adalah berbangsa Melayu, diikuti Cina sebanyak 7\%, $5 \%$ responden adalah berbangsa India, 3\% bumiputera Sabah dan 1\% daripada responden ialah bumiputera Sarawak. Dari segi pola tempat tinggal responden pula, kebanyakan responden berasal dan menetap di bandar $(n=176)$ dan 127 orang responden berasal dari kawasan luar bandar. 
Farahah Rosni et al.

Jadual 1: Ciri-ciri demografik responden

\begin{tabular}{lcc}
\hline Pemboleh ubah & Frekuensi & $\%$ \\
\hline Jantina & & \\
Lelaki & 46 & 15 \\
Perempuan & 257 & 85 \\
Bangsa & & \\
Melayu & 254 & 84 \\
Cina & 21 & 7 \\
India & 15 & 5 \\
Bumiputera Sabah & 9 & 1 \\
Bumiputera Sarawak & 4 & 1 \\
Tempat tinggal & & \\
Bandar & 176 & 58 \\
Luar bandar & 127 & 42 \\
\hline
\end{tabular}

\section{Alat Soal Selidik}

Kajian ini menggunakan soal selidik daripada Fear of Crime in America Survey (Ferraro 1995) yang telah diadaptasi kepada bahasa Melayu supaya bersesuaian dengan konteks budaya Malaysia dengan menggunakan kaedah terjemahan berbalik, iaitu forward-backward. Setelah proses terjemahan berbalik selesai, pengesahan kandungan telah dilakukan bagi memastikan alat soal selidik yang digunakan dalam kajian ini dapat mewakili dan juga relevan dengan konstruk yang dikaji. Pengesahan kandungan telah dilakukan oleh pakar dan penyelia kajian ini. Soalan-soalan yang tidak difahami atau tidak bersesuaian dengan dimensi yang ingin diukur, struktur budaya atau undang-undang Malaysia telah ditekankan oleh pakar dan dikeluarkan daripada soal selidik sebelum diedarkan kepada respondenresponden kajian rintis.

Setelah kesahan kandungan alat soal selidik ini dipersetujui oleh pakar bidang, kesahan muka pula dilakukan dalam kalangan 10 pelajar universiti bagi menguji tahap pemahaman bahasa yang digunakan dalam alat soal selidik. Maklum balas daripada responden kesahan muka ini menunjukkan bahawa item-item yang dikemukakan adalah mudah difahami, bersesuaian dan mencukupi. Seterusnya, kajian rintis juga dilakukan dalam kalangan 50 responden di salah sebuah universiti di Lembah Klang bagi menguji tahap kebolehpercayan dan kesahan konstruk item-item dalam alat soal-selidik. Responden yang menyertai kajian rintis ini tidak dibenarkan untuk menyertai kajian sebenar yang dijalankan kemudian. Setelah data dipungut, kebolehpercayaan telah dianalisis dengan menggunakan kaedah pekali 
Alfa Cronbach bagi menentukan ketekalan dalaman instrumen manakala analisis faktor telah dilakukan untuk menguji muatan faktor setiap item (Mohammad Rahim, Nadiah Syariani dan Geshina Ayu 2013; Mohammad Rahim et al. 2017).

Hasil analisis kebolehpercayaan alat ujian yang digunakan semasa menjalankan kajian rintis menunjukkan bahawa dimensi ketakutan terhadap jenayah mempunyai nilai alfa Cronbach $\alpha=0.938$, dimensi tahap keselamatan mempunyai nilai alfa Cronbach $\alpha=0.850$, dimensi persepsi risiko menjadi mangsa menghasilkan nilai alfa Cronbach $\alpha=0.957$ dan dimensi tingkah laku berjaga- jaga mempunyai nilai alfa Cronbach $\alpha=0.831$. Seperti yang dicadangkan oleh Kaplan dan Sacuzzo (1993), nilai alfa Cronbach bagi keempat-empat dimensi ini adalah tinggi dan baik untuk tujuan penyelidikan. Kesahan konstruk pula menunjukkan semua item mempamerkan nilai muatan faktor lebih daripada 0.40 di mana ia dianggap baik (Hair et al. 2010).

Terdapat lima bahagian utama dalam soal selidik ini, iaitu Bahagian A, B, C, D dan E. Bahagian A ialah bahagian demografi yang terdiri daripada butiran peribadi responden iaitu jantina, umur, bangsa dan kawasan tempat tinggal. Seterusnya ialah bahagian B yang dipecahkan kepada dua subdimensi, iaitu tahap ketakutan terhadap jenayah dan tahap keselamatan. Terdapat 12 soalan yang terkandung dalam dimensi tahap ketakutan terhadap jenayah. Kaedah pemarkahan bagi dimensi ini adalah menggunakan skala Likert 1 hingga 5; (1) tidak takut langsung, (2) tidak takut, (3) sedikit takut, (4) takut, dan (5) sangat takut.

Manakala, terdapat lima soalan bagi dimensi tahap keselamatan yang diukur menggunakan skala Likert 1 hingga 4; (1) sangat selamat, (2) selamat, (3) tidak selamat, dan (4) sangat tidak selamat. Terdapat tujuh soalan di bahagian $\mathrm{C}$, iaitu mengukur persepsi risiko menjadi mangsa dengan kaedah pemarkatan skala Likert 1 hingga 5; (1) sangat tidak mungkin berlaku, (2) tidak mungkin berlaku, (3) sedikit kemungkinan berlaku, (4) kemungkinan berlaku, dan (5) sangat kemungkinan berlaku. Maklumat sejarah mangsa jenayah diperoleh melalui enam soalan "Ya" dan "Tidak" dan pengelasan senjata yang terlibat ketika menjadi mangsa jenayah.

Bahagian seterusnya mengandungi 18 soalan untuk mengukur tingkah laku berjaga-jaga yang diadaptasi oleh responden bagi mengawal ketakutan terhadap jenayah. Responden menjawab dengan melaporkan seberapa kerap mereka terlibat dengan tingkah laku tertentu untuk meningkatkan keselamatan dengan menggunakan skala Likert 1 hingga 4; (1) tidak pernah, (2) jarang, (3) kadangkadang, dan (4) selalu atau setiap masa. Data yang dikumpul daripada soal selidik telah dijadualkan untuk melihat purata dan sisihan piawai menggunakan perisian IBM SPSS Versi 22. Analisis ujian- $t$ sampel bebas juga dijalankan menggunakan perisian yang sama selepas mendapati data kajian tertabur secara normal. 


\section{DAPATAN KAJAN}

Jadual 2 menunjukkan bahawa min skor tahap ketakutan terhadap jenayah $(51.50 \pm$ 7.99), tahap keselamatan $(11.10 \pm 2.24)$, persepsi risiko menjadi mangsa (22.05 \pm $6.65)$ dan tingkah laku berjaga-jaga (52.63 \pm 7.24$)$ adalah tinggi. Bagi menerangkan paras tinggi atau rendah bagi setiap satu bahagian, skor bagi setiap bahagian telah dikumpulankan kepada tiga paras, iaitu rendah, sederhana dan tinggi. Seperti dalam Jadual 3, majoriti daripada pelajar menunjukkan tahap ketakutan terhadap jenayah yang tinggi $(62.8 \%)$, tahap keselamatan yang sederhana $(71.3 \%)$, mempunyai persepsi risiko menjadi mangsa yang sederhana (51.2\%) dan mengamalkan tingkah laku berjaga-jaga pada tahap yang sederhana (52.5\%).

Profil sejarah mangsa jenayah telah dijana untuk mengetahui komposisi mangsa jenayah dalam kalangan pelajar universiti. Daripada 303 pelajar yang terlibat dalam kajian ini, 236 orang $(77.9 \%)$ langsung tidak pernah menjadi mangsa manakala 67 orang (22.1\%) pernah menjadi mangsa jenayah. Daripada 67 orang, 13 orang daripada mangsa jenayah tersebut ialah lelaki dan 54 mangsa lagi ialah perempuan. Jadual 4 menerangkan dengan lebih lanjut profil sejarah mangsa jenayah yang diperoleh daripada kajian ini.

Ujian- $t$ sampel bebas telah dijalankan untuk membandingkan skor min tahap ketakutan, tahap keselamatan, persepsi risiko menjadi mangsa dan tingkah laku berjaga-jaga antara pelajar lelaki dengan perempuan (Jadual 5). Hasil analisis mendapati bahawa pelajar perempuan mempunyai tahap ketakutan lebih tinggi yang signifikan secara statistik $(52.35 \pm 7.47)$ berbanding pelajar lelaki $(46.25 \pm 8.78)[t(301)=-5.041, p<0.05]$. Manakala, tiada perbezaan yang signifikan antara pelajar lelaki $(10.65 \pm 2.16)$ dengan perempuan $(11.18 \pm 2.25)$ terhadap tahap keselamatan $[t(301)=-1.460, p>0.05]$.

Persepsi risiko menjadi mangsa antara lelaki $(20.83 \pm 6.59)$ dengan perempuan $(22.27 \pm 6.66)$ juga tidak menunjukkan perbezaan yang signifikan $[t(301)=-1.356, p>0.05]$. Namun begitu, hasil analisis mendapati bahawa pelajar perempuan (53.41 \pm 6.51$)$ mengamalkan tingkah laku berjaga-jaga yang lebih tinggi berbanding pelajar lelaki $(48.28 \pm 9.37)[t(301)=-3.559, p<0.05]$. Dapatan kajian diperihalkan dalam Jadual 5.

Seterusnya, kajian ini ingin melihat perbezaan tahap ketakutan terhadap jenayah, tahap keselamatan, persepsi risiko menjadi mangsa dan tingkah laku berjaga-jaga mengikut kawasan tempat tinggal dalam kalangan pelajar universiti. Berdasarkan Jadual 6, hasil analisis ujian- $t$ sampel bebas mendapati bahawa tiada perbezaan ketakutan terhadap jenayah yang signifikan antara mereka yang tinggal di bandar $(50.83 \pm 7.84)$ dengan yang tinggal di luar bandar $(52.45 \pm 8.12)$ $[t(301)=-1.751, p>0.05]$. 
Tahap keselamatan $[t(301)=-0.511, p>0.05]$ dan persepsi risiko menjadi mangsa $[t(301)=0.897, p>0.05]$ juga tidak menunjukkan perbezaan yang signifikan antara yang tinggal di bandar $(11.04 \pm 2.19),(22.34 \pm 6.34)$ dengan yang tinggal di luar bandar $(11.17 \pm 2.43),(21.65 \pm 7.07)$. Namun begitu, hasil analisis mendapati bahawa mereka yang tinggal di bandar $(53.38 \pm 6.90)$ mengamalkan tingkah laku berjaga-jaga yang lebih tinggi berbanding mereka yang tinggal di luar bandar $(51.59 \pm 7.60)[t(301)=2.136, p<0.05]$.

Ujian- $t$ sampel bebas dilakukan antara setiap bahagian kajian dan sejarah menjadi mangsa jenayah. Hasil analisis mendapati bahawa kesemua dimensi; ketakutan terhadap jenayah, tahap keselamatan, persepsi risiko menjadi mangsa tidak mempunyai perbezaan yang signifikan dengan sejarah menjadi mangsa jenayah (Jadual 7).

Jadual 2: Nilai minimun, maksimum, dan sisihan piawai setiap bahagian $(n=303)$

\begin{tabular}{lcccc}
\hline Dimensi & Nilai minimum & Nilai maksimum & Min & SP \\
\hline $\begin{array}{l}\text { Tahap ketakutan } \\
\text { terhadap jenayah }\end{array}$ & 18 & 60 & 51.50 & 7.99 \\
$\begin{array}{l}\text { Tahap keselamatan } \\
\begin{array}{l}\text { Persepsi risiko menjadi } \\
\text { mangsa }\end{array}\end{array}$ & 5 & 19 & 11.10 & 2.24 \\
$\begin{array}{l}\text { Tingkah laku berjaga- } \\
\text { jaga }\end{array}$ & 32 & 35 & 22.05 & 6.65 \\
\hline
\end{tabular}

Jadual 3: Paras tahap ketakutan terhadap jenayah, tahap keselamatan, persepsi risiko dan tingkah laku berjaga-jaga dalam kalangan pelajar universiti

\begin{tabular}{llcc}
\hline \multirow{2}{*}{ Dimensi } & Pemarkatan (skala skor) & \multicolumn{2}{c}{$n=303$} \\
\cline { 3 - 4 } & & Kekerapan & Peratusan (\%) \\
\hline Tahap ketakutan terhadap & Rendah (12-27) & 3 & 1.0 \\
jenayah & Sederhana (28-43) & 49 & 16.2 \\
& Tinggi (44-60) & 251 & 62.8 \\
Tahap keselamatan & Rendah (15-20) & 22 & 7.3 \\
& Sederhana (10-15) & 216 & 71.3 \\
\multirow{2}{*}{$\begin{array}{l}\text { Persepsi risiko menjadi } \\
\text { mangsa }\end{array}$} & Tinggi (5-9) & 65 & 21.5 \\
& Rendah (7-16) & 66 & 21.8 \\
& Sederhana (17-26) & 155 & 51.2 \\
& Tinggi (27-35) & 82 & 27.1 \\
\hline
\end{tabular}


Farahah Rosni et al.

Jadual 3: (bersambung)

\begin{tabular}{llcc}
\hline \multirow{2}{*}{ Dimensi } & Pemarkatan (skala skor) & \multicolumn{2}{c}{$n=303$} \\
\cline { 3 - 4 } & & Kekerapan & Peratusan (\%) \\
\hline Tingkah laku berjaga- jaga & Rendah (18-35) & 4 & 1.3 \\
& Sederhana (36-53) & 159 & 52.5 \\
& Tinggi (54-72) & 140 & 46.2 \\
\hline
\end{tabular}

Jadual 4: Profil jenis jenayah, bilangan mangsa, bilangan yang melaporkan kepada polis dan senjata yang terlibat

\begin{tabular}{|c|c|c|c|c|}
\hline \multirow{2}{*}{ Jenis jenayah } & \multicolumn{2}{|c|}{ Bilangan mangsa } & \multirow{2}{*}{$\begin{array}{c}\text { Bilangan yang } \\
\text { membuat } \\
\text { laporan polis }\end{array}$} & \multirow{2}{*}{$\begin{array}{l}\text { Senjata yang } \\
\text { terlibat }\end{array}$} \\
\hline & Lelaki & Perempuan & & \\
\hline $\begin{array}{l}\text { Jenayah harta (dirompak, } \\
\text { dicuri) }\end{array}$ & 6 & 26 & 17 & Tiada \\
\hline $\begin{array}{l}\text { Jenayah harta melibatkan } \\
\text { kekerasan }\end{array}$ & 1 & 3 & 3 & $\begin{array}{l}\text { Senjata api (2), } \\
\text { Tiada (2) }\end{array}$ \\
\hline Diugut pukul atau serang & 4 & 3 & - & - \\
\hline Dicederakan atau dipukul & 0 & 2 & 0 & Kekerasan fizikal \\
\hline $\begin{array}{l}\text { Dipaksa mengadakan } \\
\text { hubungan seksual }\end{array}$ & 4 & 19 & 6 & $\begin{array}{l}\text { Kekerasan fizikal } \\
(15), \\
\text { lain-lain senjata (8) }\end{array}$ \\
\hline $\begin{array}{l}\text { Mendapat gangguan } \\
\text { seksual (disentuh, diraba, } \\
\text { dipaksa peluk atau cium) }\end{array}$ & 5 & 14 & 0 & $\begin{array}{l}\text { Kekerasan fizikal } \\
\text { (10), lain-lain } \\
\text { senjata (3), tidak } \\
\text { dilaporkan (6) }\end{array}$ \\
\hline
\end{tabular}

Jadual 5: Ujian- $t$ tahap ketakutan, tahap keselamatan, persepsi risiko menjadi mangsa dan tingkah laku berjaga-jaga antara jantina

\begin{tabular}{|c|c|c|c|c|c|c|}
\hline Dimensi & Jantina & $n$ & Min & SP & $t$ & $p$ \\
\hline \multirow{2}{*}{$\begin{array}{l}\text { Tahap ketakutan terhadap } \\
\text { jenayah }\end{array}$} & Lelaki & 46 & 46.25 & 8.78 & \multirow{2}{*}{-5.041} & \multirow{2}{*}{$0.00^{*}$} \\
\hline & Perempuan & 257 & 52.35 & 7.47 & & \\
\hline \multirow[t]{2}{*}{ Tahap keselamatan } & Lelaki & 46 & 10.65 & 2.16 & \multirow{2}{*}{-1.460} & \multirow{2}{*}{0.15} \\
\hline & Perempuan & 257 & 11.18 & 2.25 & & \\
\hline \multirow{2}{*}{$\begin{array}{l}\text { Persepsi risiko menjadi } \\
\text { mangsa }\end{array}$} & Lelaki & 46 & 20.83 & 6.59 & \multirow{2}{*}{-1.356} & \multirow{2}{*}{0.18} \\
\hline & Perempuan & 257 & 22.27 & 6.66 & & \\
\hline \multirow[t]{2}{*}{ Tingkah laku berjaga-jaga } & Lelaki & 46 & 48.28 & 9.37 & \multirow{2}{*}{-3.559} & \multirow{2}{*}{$0.00^{*}$} \\
\hline & Perempuan & 257 & 53.41 & 6.51 & & \\
\hline
\end{tabular}

"nilai $p$ adalah signifikan $p<0.05$ 
Jadual 6: Ujian- $t$ tahap ketakutan terhadap jenayah, tahap keselamatan, persepsi risiko menjadi mangsa dan tingkah laku berjaga-jaga antara kawasan tempat tinggal

\begin{tabular}{llccccc}
\hline Dimensi & $\begin{array}{l}\text { Kawasan } \\
\text { tempat tinggal }\end{array}$ & $n$ & Min & SP & $t$ & $p$ \\
\hline Tahap ketakutan terhadap & Bandar & 176 & 50.83 & 7.84 & -1.751 & 0.08 \\
jenayah & Luar bandar & 127 & 52.45 & 8.12 & & \\
Tahap keselamatan & Bandar & 176 & 11.04 & 2.19 & -0.511 & 0.61 \\
& Luar bandar & 127 & 11.17 & 2.43 & & \\
Persepsi risiko menjadi & Bandar & 176 & 22.34 & 6.34 & \multirow{2}{*}{0.897} & 0.37 \\
mangsa & Luar bandar & 127 & 21.65 & 7.07 & & \multirow{2}{*}{$0.03^{*}$} \\
Tingkah laku berjaga-jaga & Bandar & 176 & 53.38 & 6.90 & 2.136 & 0.00 \\
& Luar bandar & 127 & 51.59 & 7.60 & & \\
\hline
\end{tabular}

"nilai $p$ adalah signifikan $p<0.05$

Jadual 7: Ujian- $t$ tahap ketakutan terhadap jenayah, tahap keselamatan, persepsi risiko menjadi mangsa dan tingkah laku berjaga-jaga antara sejarah menjadi mangsa jenayah

\begin{tabular}{llccccc}
\hline Dimensi & $\begin{array}{l}\text { Sejarah mangsa } \\
\text { jenayah }\end{array}$ & $n$ & Min & SP & $t$ & $p$ \\
\hline Ketakutan terhadap & Tidak pernah & 236 & 51.75 & 8.03 & \multirow{2}{*}{0.969} & 0.33 \\
jenayah & Pernah & 67 & 50.67 & 7.81 & & \\
Tahap keselamatan & Tidak pernah & 236 & 11.16 & 2.28 & \multirow{2}{*}{0.951} & 0.34 \\
& Pernah & 67 & 10.87 & 2.10 & & \\
Persepsi risiko menjadi & Tidak pernah & 236 & 21.73 & 6.68 & \multirow{2}{*}{0.557} & \multirow{2}{*}{0.12} \\
mangsa & Pernah & 67 & 23.16 & 6.50 & & \\
Tingkah laku berjaga-jaga & Tidak pernah & 236 & 52.50 & 7.21 & -0.588 & 0.58 \\
& Pernah & 67 & 53.09 & 7.40 & & \\
\hline
\end{tabular}

\section{PERBINCANGAN DAN IMPLIKASI KAJIAN}

Melalui kajian ini, pelajar universiti di Malaysia menunjukkan tahap ketakutan yang sangat tinggi, mempersepsikan tahap keselamatan yang sederhana, berasakan diri mereka agak berisiko menjadi mangsa jenayah, serta kerap mengamalkan tingkah laku berjaga-jaga. Menurut Grinshteyn et al. (2016), mereka yang mempunyai tahap pendidikan tinggi mempunyai tahap ketakutan yang lebih rendah berbanding yang berpendidikan rendah. Hal ini disebabkan oleh efikasi kendiri yang tinggi hasil pendidikan yang tinggi menyebabkan ketakutan terhadap jenayah dalam kalangan mereka yang berpelajaran adalah rendah. Namun begitu, kajian ini hanya 
dilimitasikan terhadap pelajar universiti dan perbandingan ketakutan terhadap jenayah antara individu berpendidikan tinggi dengan rendah tidak dapat dijalankan.

Berdasarkan analisis deskriptif, terdapat 67 orang pelajar yang pernah menjadi mangsa jenayah, 13 daripadanya ialah pelajar lelaki dan selebihnya ialah pelajar perempuan. Sebahagian besar kes jenayah yang dialami oleh pelajar universiti ialah jenayah kekerasan, iaitu sebanyak 55 kes, berbanding jenayah harta sebanyak 32 kes. Selain itu, jenayah kekerasan yang mencatatkan bilangan mangsa yang paling tinggi ialah gangguan seksual atau rogol berbanding dengan jenayah kekerasan yang lain. Namun begitu, walaupun jenayah kekerasan mencatatkan kes yang paling tinggi, jenayah jenis ini adalah yang paling kurang dilaporkan kepada pihak polis berbanding jenayah harta. Hal ini mungkin dapat menjelaskan dark figures dalam statistik jenayah di Malaysia kerana menurut Amar (2006), 90\% daripada jenayah di Malaysia adalah daripada jenayah harta dan selebihnya ialah jenayah kekerasan. Namun, apabila kajian ini dijalankan, jenayah kekerasan menunjukkan catatan kes lebih tinggi berbanding jenayah harta.

Hasil kajian ini mendapati bahawa pelajar perempuan menunjukkan tahap ketakutan terhadap jenayah yang lebih tinggi berbanding pelajar lelaki. Kajiankajian sebelum ini juga mendapati bahawa wanita mempunyai tahap ketakutan yang lebih tinggi berbanding lelaki walaupun lelaki adalah lebih cenderung menjadi mangsa jenayah kecuali rogol, lalu hal ini menghasilkan paradoks-jantina (Boateng dan Adjekum-Boateng 2017; Vauclair dan Bratanova 2017).

Terdapat pendapat bahawa penyebab perempuan lebih menakuti jenayah berpunca daripada kemungkinan peningkatan menjadi mangsa jenayah tertentu seperti rogol. Dobbs, Waid dan Shelly (2009) mendapati bahawa apabila jenayah rogol dikawal, terdapat persamaan jumlah ketakutan antara lelaki dengan perempuan. Hal ini disebabkan oleh hakikat bahawa ketakutan terhadap jenayah rogol cenderung untuk menjadi lebih tinggi, terutamanya perempuan, daripada ketakutan terhadap jenayah lain.

Oleh itu, ketakutan terhadap jenayah rogol dalam kalangan wanita sering membayangi ketakutan terhadap jenayah tertentu yang lain, sepertimana yang diterangkan dalam Teori Bayangan Serangan Seksual (The Shadow of Sexual Assault Theory) (Ferraro 1995). Teori ini menyatakan bahawa wanita berasa sangat takut terhadap jenayah rogol dan terutamanya bahaya yang dihadapi seperti kematian sebagai hasil jenayah rogol. Jenayah rogol ini telah bertindak sebagai master offense, lalu meningkatkan juga ketakutan mereka terhadap jenayah bukan seksual. Hal ini kerana golongan wanita menyedari bahawa menjadi mangsa dalam apa sahaja jenis jenayah berkemungkinan mengarah kepada serangan seksual. Dengan kata lain, disebabkan persepsi risiko rogol meningkat, wanita berasa lebih takut terhadap jenayah rogol dan situasi rogol ini memberikan kesan ketakutan terhadap semua jenis jenayah. 
Penjelasan lain berhubungan dengan faktor jantina dan ketakutan terhadap jenayah adalah berkisarkan sosialisasi. Golongan wanita disosialisasikan untuk percaya bahawa mereka lebih lemah dan kurang agresif daripada lelaki, dan tingkah laku yang mematuhi ideologi ini diperkukuh secara sengaja dan tidak sengaja (Cops dan Pleysier 2011; Rader dan Cossman 2011).

Snedker (2006) mendapati bahawa terdapat bias sosialisasi apabila remaja perempuan lebih terbuka membincangkan ketakutan terhadap jenayah, manakala remaja lelaki seolah-olah berurusan dengan emosi itu secara dalaman. Hal ini kerana wanita diajar untuk mengekspresi emosi mereka, manakala lelaki mempelajari bahawa dengan bersikap tabah dan autonomi adalah lebih maskulin, lalu golongan lelaki mungkin kurang cenderung untuk melaporkan ketakutan terhadap jenayah (Cops dan Pleysier 2011; Snedker 2006).

Tahap keselamatan merupakan satu dimensi yang dikaji dalam kajian ketakutan terhadap jenayah ini. Ia menunjukkan bahawa tiada perbezaan antara pelajar lelaki dengan perempuan. Dapatan ini bercanggah dengan kebanyakan kajian lepas yang mendapati bahawa wanita lebih cenderung untuk berasa tidak selamat berbanding lelaki. Ratnayake (2016) mendapati bahawa pelajar perempuan di sekitar Bendigo, Australia berasa kurang selamat berbanding lelaki pada waktu malam pada hari minggu dan hujung minggu. Johnson (2005) pula mendapati bahawa wanita Australia berasa sedikit tidak selamat sebanyak dua kali ganda berbanding lelaki. Pada masa yang sama, wanita juga berasa sangat tidak selamat berjalan seorang diri di kawasan tempatan pada waktu gelap sebanyak empat kali ganda lebih berbanding lelaki.

Hasil ini menunjukkan bahawa pelajar lelaki juga mengambil berat tentang tahap keselamatan mereka dan mungkin kerana mereka menyedari jenayah boleh berlaku kepada sesiapa sahaja tanpa mengira jantina. Sepertimana analisis jenayah kekerasan di Malaysia yang mendapati bahawa sebenarnya lelaki adalah dua kali ganda lebih banyak menjadi mangsa daripada perempuan dan purata kadar mangsa pembunuhan paling tinggi di Malaysia adalah dalam kalangan lelaki (Mohammad Rahim, Nadiah Syariani dan Geshina Ayu 2014).

Selain itu, persepsi risiko menjadi mangsa juga tidak menunjukkan perbezaan antara pelajar lelaki dengan perempuan. Hasil dapatan ini sekali lagi bercanggah dengan kajian May, Rader dan Goodrum (2010) yang mendapati bahawa perempuan mempunyai persepsi risiko menjadi mangsa yang lebih tinggi berbanding lelaki, terutamanya dalam kalangan perempuan yang pernah menjadi mangsa jenayah harta benda, mangsa jenayah seksual dan mangsa jenayah kekerasan bukan seksual.

Hasil kajian ini mendapati bahawa ketakutan terhadap jenayah mempunyai perbezaan yang begitu signifikan antara jantina, tetapi yang menariknya, persepsi risiko menjadi mangsa tidak ada perbezaan antara pelajar lelaki dengan perempuan. Namun begitu, menurut Crowl dan Battin (2016), persepsi risiko merupakan 
peramal kepada ketakutan terhadap jenayah, iaitu mereka yang mempunyai persepsi risiko yang tinggi akan menunjukkan ketakutan yang tinggi. Walau bagaimanapun, kajian ini mendapati bahawa tiada perbezaan persepsi risiko antara pelajar lelaki dengan perempuan tetapi terdapat perbezaan yang ketara dalam ketakutan terhadap jenayah.

Perkara ini mungkin boleh dijelaskan melalui kajian Sutton dan Farrall (2005) yang mendapati skala penipuan yang tinggi dalam kajiannya dan mengimplikasi bahawa lelaki lebih memendamkan perasaan takut akan jenayah. Namun, apabila lelaki lebih jujur dengan perasaan mereka, ketakutan terhadap jenayah dilaporkan lebih tinggi daripada perempuan. Keputusan kajian Sutton dan Farrall mencadangkan bahawa lelaki berasakan tekanan untuk memendam ekspresi ketakutan terhadap jenayah mereka berbanding perempuan. Hal ini kerana kaum lelaki berasakan mengekspresi ketakutan terhadap jenayah secara terbuka tidak diterima secara sosial lalu memendamkan perasaan tersebut.

Perbezaan tingkah laku berjaga-jaga antara jantina yang dijalankan dalam kajian ini mendapati bahawa terdapat pelajar perempuan secara signifikan mengadaptasi tingkah laku berjaga-jaga. Kajian ini disokong oleh kajian-kajian lepas yang mendapati bahawa wanita lebih cenderung melakukan tingkah laku berjaga-jaga seperti tingkah laku pengelakan dan mempertahankan diri (Badiora, Popola dan Fadoyin 2014; Ratnayake 2016; Yirmibesoglu dan Ergun 2015). Kajian yang dijalankan di Malaysia juga mendapati bahawa wanita lebih banyak menunjukkan tingkah laku mempertahankan diri dengan membawa sekurangkurangnya satu item untuk melindungi diri mereka daripada bahaya (Maruthaveeran dan Van den Bosh 2015).

Selain itu, hipotesis kerentanan juga boleh menjelaskan keadaan ini. Perempuan berasa mereka lebih rentan menjadi mangsa jenayah kerana berasa diri mereka lemah daripada segi fizikal dan tidak mampu melawan pemangsa terutamanya jika pemangsa ialah lelaki dan bersaiz lebih besar daripada mereka (Rader dan Cossman 2011; Scarborough et al. 2010). Oleh sebab persepsi kerentanan ini, berkemungkinan menyebabkan pelajar perempuan lebih cenderung mengamalkan tingkah laku berjaga-jaga supaya dapat melepaskan diri daripada bahaya atau serangan.

Ketakutan terhadap jenayah antara pelajar yang menetap di bandar dengan luar bandar tidak menunjukkan perbezaan yang ketara. Hasil kajian ini tidak konsisten dengan dapatan Burruss, Shafer dan Giblin (2010) yang mendapati bahawa pelajar di kampus bandar menunjukkan ketakutan terhadap jenayah yang lebih tinggi. Kajian-kajian lain juga mendapati bahawa sememangnya mereka yang tinggal di luar bandar mempunyai ketakutan yang lebih rendah dan penduduk bandar secara signifikan menunjukkan ketakutan yang lebih tinggi (Will 1995; Yarwood and Gardner 2000). 
Selain itu, melalui kajian ini, tahap keselamatan juga tidak menunjukkan perbezaan antara pelajar yang berasal dari bandar atau luar bandar. Hasil kajian ini disokong oleh Agubokwu (2016) yang mendapati bahawa tiada perbezaan tahap keselamatan antara pelajar bandar dengan luar bandar di sekitar kawasan pertengahan Atlantik. Namun, dapatan ini juga tidak konsisten dengan kajiankajian lepas. Kajian Zuckerman (2010) dan Lippman, Burns dan McArthur (1996) yang menggunakan sampel pelajar sekolah mendapati bahawa pelajar di kawasan bandar berasa lebih tidak selamat berbanding pelajar yang menuntut di kawasan luar bandar.

Persepsi risiko menjadi mangsa juga tidak menunjukkan sebarang perbezaan antara pelajar yang menetap di bandar dengan luar bandar. Hasil ini bercanggah dengan kajian Agubokwu (2016) yang mendapati bahawa pelajar kolej di luar bandar adalah berbeza dengan pelajar di bandar, di mana pelajar kolej di bandar mempunyai persepsi risiko untuk menjadi mangsa lebih tinggi daripada pelajar di kawasan luar bandar. Kajian Gainey dan Seyfrit (2001) mendapati bahawa golongan muda di kawasan luar bandar Virginia juga menunjukkan ketakutan terhadap jenayah yang tinggi kerana mempersepsikan diri mereka lebih berisiko menjadi mangsa jenayah.

Pelajar bandar dan luar bandar menunjukkan tahap ketakutan terhadap jenayah yang sama tinggi walaupun Muhammad Amin, Mohammad Rahim dan Geshina Ayu (2014) mendapati jenayah kekerasan lebih kerap berlaku di kawasan bandar berbanding luar bandar di Malaysia. Namun begitu, dari segi jenayah harta pula, kawasan bandar yang mempunyai pendapatan rumah yang tinggi seperti Kuala Lumpur, Johor dan Negeri Sembilan menunjukkan kadar jenayah harta yang rendah. Manakala, kawasan pantai timur Malaysia yang kebanyakannya adalah luar bandar dan mempunyai pendapatan rumah yang lebih rendah berbanding di pantai barat Semenanjung Malaysia menunjukkan kadar jenayah harta yang lebih tinggi (Syerrina dan Nuzlinda 2016).

Keterangan di atas dibuktikan lagi apabila menurut Gainey dan Seyfrit (2001), walaupun jenayah kurang berlaku di luar bandar berbanding di kawasan bandar, terdapat banyak sebab untuk penduduk luar bandar menjadi takut. Pertama, terdapat beberapa bukti bahawa jenis jenayah berbeza di seluruh lokasi geografi. Terdapat perbezaan nisbah yang besar antara kes rogol dengan rompakan dan kedua-duanya memprovokasi keselamatan wanita dan selalunya tidak dilaporkan. Kedua, penduduk luar bandar, terutamanya, mengambil berat tentang jenayah harta benda.

Walaupun ketakutan terhadap jenayah, tahap keselamatan dan persepsi risiko tidak menunjukkan perbezaan antara pelajar yang tinggal di bandar dengan luar bandar, kajian ini mendapati bahawa pelajar yang tinggal di bandar lebih kerap mengamalkan tingkah laku berjaga-jaga berbanding pelajar di luar bandar. Hal ini mungkin kerana jeleketan hubungan antara penduduk luar bandar yang 
lebih kerap terlibat dalam organisasi komuniti, kepercayaan dan hubungan kejiranan yang tinggi dan berasa lebih selamat berbanding penduduk bandar (Palmer et al. 2005). Manakala kajian Abdul Aziz et al. (2016) menunjukkan keterlibatan sosial penduduk bandar dalam membanteras jenayah adalah rendah mungkin menyebabkan mereka yang berada di bandar berasakan perlunya untuk mempertahankan diri sendiri.

Kesimpulannya, hasil kajian ini mendapati bahawa tiada perbezaan antara tahap ketakutan, tahap keselamatan dan persepsi risiko menjadi mangsa antara pelajar yang berasal dari luar bandar dan bandar. Walau bagaimanapun, kebanyakan kajian lalu mendapat hasil yang sebaliknya. Hal ini mungkin kerana, pertama, kajian ini mengkaji ketakutan terhadap jenayah secara am tanpa mengkhususkan lokasi seperti kawasan kejiranan atau kawasan tempat tinggal. Kedua, mungkin berlakunya proses asimilasi di mana pelajar dari luar bandar yang datang ke kawasan bandar, telah mengadaptasi dengan cara hidup dan keadaan di bandar lalu menyebabkan tahap ketakutan, keselamatan dan persepsi risiko mereka tiada beza dengan pelajar yang sememangnya menetap di bandar.

Berdasarkan sejarah mangsa jenayah, tidak terdapat perbezaan antara ketakutan terhadap jenayah, tahap keselamatan, persepsi risiko menjadi mangsa dan tingkah laku berjaga-jaga antara pelajar yang pernah menjadi mangsa dengan pelajar yang tidak pernah menjadi mangsa jenayah. Hasil kajian ini disokong oleh Crowl dan Battin (2016) yang mendapati bahawa tiada perbezaan ketakutan terhadap jenayah antara mangsa dengan bukan mangsa dalam kedua-dua jenayah harta dan kekerasan. Allen (2013) juga menegaskan bahawa tiada perbezaan ketakutan terhadap jenayah antara mereka yang pernah menjadi mangsa atau tidak, terutamanya jenayah seksual.

Namun begitu, terdapat juga kajian-kajian yang berbeza pendapat daripada hasil kajian ini. Zarafonitou (2008) mendapati bahawa mangsa jenayah di Greece berasa takut dan tidak selamat tiga kali ganda lebih berbanding mereka yang tidak pernah menjadi mangsa. Walau bagaimanapun, kajiannya mendapati mereka yang tidak pernah menjadi mangsa lebih kerap mengamalkan tingkah laku mempertahankan diri. Mangsa jenayah secara langsung mempunyai tahap ketakutan terhadap jenayah yang lebih tinggi, tetapi ketakutan yang dialami hanyalah terhadap jenayah yang melibatkan mangsa tersebut (Grinshteyn et al. 2016; Hanslmeir et al. 2016).

Secara logiknya, mereka yang pernah menjadi mangsa sudah tentunya mempunyai ketakutan terhadap jenayah akibat trauma yang dialami. Namun begitu, kajian ini dan kebanyakan kajian lain mendapati bahawa terdapatnya paradoks ketakutan terhadap jenayah berdasarkan sejarah menjadi mangsa. Hal ini kerana terdapatnya persepsi kognitif terhadap risiko menjadi mangsa bagi mereka yang tidak pernah menjadi mangsa hasil daripada menyaksikan jenayah atau keganasan (Grinshteyn et al. 2016; Jarrett-luck 2015), memperoleh maklumat tentang jenayah 
melalui rangkaian sosial atau televisyen dan mereka yang mempunyai ahli keluarga atau rakan yang pernah menjadi mangsa (Wilcox, Jordan dan Pritchard 2006).

Pendapat di atas selari dengan Teori Kemangsaan Secara Langsung dan Tidak Langsung. Farrall, Gray dan Jackson (2007) menjelaskan dalam teori ini, bahawa perasaan takut terhadap jenayah dilihat sebagai hasil pengalaman menjadi mangsa jenayah. Semakin benar dan jelas pengalaman menjadi mangsa secara langsung semakin tinggi tahap ketakutan individu itu terhadap jenayah.

Namun, terdapatnya paradoks ketakutan apabila beberapa kumpulan sosial yang paling berisiko menjadi mangsa adalah yang paling kurang takut terhadap jenayah (sebagai contoh, golongan lelaki muda), dan beberapa kumpulan sosial yang paling kurang berisiko untuk menjadi mangsa menunjukkan tahap ketakutan terhadap jenayah yang lebih tinggi (sebagai contoh, perempuan dan warga tua).

Paradoks ketakutan ini sebahagiannya disebabkan kemangsaan secara tidak langsung, iaitu apabila individu mempersepsikan risiko menjadi mangsa impak daripada mendengar kejadian jenayah melalui komunikasi interpersonal. Dengan kata lain, pelajar yang tidak pernah menjadi mangsa jenayah juga menunjukkan tahap ketakutan yang tinggi kerana berkemungkinan mereka pernah menyaksikan jenayah atau mempunyai ahli keluarga atau kenalan yang pernah menjadi mangsa, lalu meningkatkan tahap ketakutan mereka juga.

Analisis faktor penyumbang terhadap ketakutan terhadap jenayah melalui kajian ini dapat memberikan kesedaran kepada semua individu, masyarakat, universiti, organisasi dan juga kerajaan. Golongan lelaki pula perlulah sedar bahawa mereka juga perlu mengamalkan tingkah laku berjaga-jaga kerana risiko mereka untuk menjadi mangsa adalah lebih tinggi daripada wanita. Masyarakat dan jiran di bandar atau luar bandar juga boleh membantu mengurangkan ketakutan terhadap jenayah dengan mewujudkan rukun tetangga dan melakukan rondaan di sekeliling kawasan perumahan secara bergilir-gilir.

Hal ini kerana masyarakat dan individu akan lebih peka dengan keadaan persekitaran kawasan kejiranan mereka berbanding hanya berprasangka buruk dengan persekitaran lalu meningkatkan ketakutan mereka terhadap jenayah dengan tidak wajar. Polisi rukun tetangga ini bukan sahaja dapat mengeratkan silaturahim dan kesefahaman antara masyarakat tetapi juga merupakan satu cara untuk mengurangkan fenomena ketakutan terhadap jenayah.

Implikasi terhadap pentadbir universiti juga perlu diberikan perhatian. Perasaan takut akan jenayah boleh dipengaruhi oleh pilihan gaya hidup pelajar. Aktiviti-aktiviti pelajar boleh memberikan kesan kepada bukan sahaja ketakutan mereka terhadap jenayah tetapi juga kepada risiko menjadi mangsa. Oleh itu, untuk membantu meningkatkan keselamatan dan kualiti hidup keseluruhan pelajar, pentadbir universiti perlu terus merangka dan melaksanakan strategi untuk meningkatkan kesedaran tentang kepentingan pilihan gaya hidup yang dibuat oleh pelajar sama ada di dalam atau di luar kampus. 
Seminar kesedaran jenayah misalnya, boleh diadakan dan maklumat diedarkan dengan menggambarkan kepada pelajar akibat yang mungkin berlaku daripada tingkah laku mereka dan bagaimana pilihan yang mereka buat boleh meningkatkan atau mengurangkan risiko menjadi mangsa dan ketakutan terhadap jenayah. Organisasi seperti pihak polis atau kerajaan boleh mengadakan kempen keselamatan awam untuk menangani ketakutan terhadap jenayah terutamanya dalam kalangan wanita untuk mengurangkan kepercayaan mereka bahawa perempuan senang menjadi mangsa sama ada di rumah atau di luar.

Seminar ini boleh dijalankan dengan mengajar asas pertahanan diri dan penggunaan alat perlindungan diri, seperti semburan lada yang dapat meningkatkan keyakinan diri mereka. Selain itu, kempen atau seminar yang dijalankan ini perlulah juga difokuskan kepada kaum lelaki supaya mereka tidak beranggapan bahawa mengakui ketakutan terhadap jenayah atau pernah menjadi mangsa dalam apa jua jenis jenayah tidak diterima oleh masyarakat.

\section{CADANGAN DAN KESIMPULAN}

Kajian ini mendapati bahawa terdapat perbezaan jantina dalam ketakutan terhadap jenayah dan tingkah laku berjaga-jaga tetapi tidak terhadap tahap keselamatan dan persepsi risiko menjadi mangsa. Pelajar dari bandar dan luar bandar menunjukkan ketakutan terhadap jenayah, tahap keselamatan dan persepsi risiko menjadi mangsa yang hampir sama, tetapi pelajar di bandar lebih banyak melakukan tingkah laku berjaga-jaga berbanding pelajar di luar bandar. Bukan itu sahaja, kajian ini juga mendapati bahawa tiada perbezaan ketakutan terhadap jenayah, tahap keselamatan dan persepsi risiko menjadi mangsa antara pelajar yang pernah menjadi mangsa dengan yang tidak pernah menjadi mangsa.

Seperti kajian yang lain, kajian ini juga mempunyai limitasi yang perlu dijelaskan dan diakui. Pertama, data yang digunakan dalam kajian ini berbentuk keratan rentas. Oleh itu, hasil kajian ini tidak boleh digeneralisasikan terhadap populasi lain selain pelajar universiti. Selain itu, sifat kajian ini menyebabkan inferesi punca dan sebab tidak dapat dilakukan ke atas hasil kajian melainkan andaian dan kemungkinan berdasarkan kajian-kajian lepas. Hal ini kerana skop kajian ini adalah lebih kepada menganalisis perbezaan tahap sesuatu konstruk mengikut faktor sosiodemografi dan juga faktor-faktor lain.

Selain itu, walaupun kajian ini dijalankan terhadap pelajar universiti, soalan-soalan untuk mengukur ketakutan terhadap jenayah ini adalah bersifat am dan tidak dikhususkan pada kawasan kejiranan atau kawasan kampus. Oleh itu, kajian pada masa hadapan boleh dijalankan dengan mengkaji ketakutan terhadap jenayah dalam kawasan kampus universiti sahaja atau kawasan kejiranan untuk melihat perbezaannya dengan kajian ini. 
Bukan itu sahaja, walaupun terdapat perbezaan jantina terhadap ketakutan terhadap jenayah, jenis jenayah yang spesifik tidak dapat ditentukan dalam kajian ini. Terdapat kajian-kajian lalu yang mendapati bahawa tahap ketakutan perempuan lebih tinggi terhadap jenayah seksual manakala lelaki lebih menunjukkan ketakutan terhadap jenayah harta (Hale 1996; Rader dan Crossman 2011). Kajian pada masa hadapan boleh mengkaji perbezaan ketakutan terhadap jenis jenayah yang berbezabeza antara lelaki dengan perempuan.

Selain itu, kajian ini tidak dapat mengenal pasti perbezaan faktor individu dengan jenis tingkah laku berjaga-jaga (pengelakan, mempertahankan diri atau penyertaan) yang dilakukan oleh pelajar dalam mengatasi ketakutan terhadap jenayah. Kajian pada masa hadapan boleh menghasilkan profil ketakutan terhadap jenayah yang lebih terperinci dengan mengambil berat limitasi kajian ini.

\section{RUJUKAN}

Abdul Aziz Rahman, Abdul Razaq Ahmad, Jalaluddin Abdul Malek and Mohd Mahzan Awang. 2016. Penglibatan sosial dan pembudayaan nilai murni melalui pembelajaran tidak formal dalam kalangan penduduk bandar Putrajaya. Kajian Malaysia 34(2): 75-100. https://doi.org/10.21315/km2016.34.2.4

Agubokwu, V.O. 2016. Student perceptions of safety at urban, suburban and rural community colleges. PhD diss., Morgan State University.

Aldrin Abdullah, Massoomeh Hedayati Marzbali, Mohammad Javad Maghsoodi Tilaki and Azizi Bahauddin. 2015. Territorial features, disorder and fear of crime in residential neighbourhoods in Malaysia: Testing for multigroup invariance. Global Crime 16(3): 197-218. https://doi.org/10.1080/17440572.2015.1019611

Allen, J. 2006. Worry about crime in England \& Wales: Findings from the 2003/04 and 2004/05 British crime survey. London: Great Britain Home Office Research Development and Statistics Directorate.

Allen, W.D. 2013. Self protection against crime victimzation: Theory and evidence from university campuses. International Review if Law and Economics 34: 21-33. https://doi.org/10.1016/j.irle.2012.11.002

Amar, S. 2006. Crime levels and trends in the next decade. Journal of the Kuala Lumpur Royal Malaysia Police College 5: 1-13.

Amin Khan. 2015. The different views of crime. The Star Online. http://www.thestar. com.my/news/nation/2015/02/27/the-different-views-of-crime-there-is-a-gapbetween-the-reality-of-crime-and-public-perception (accessed 10 March 2017).

Austin, D.M., L.A. Furr and M. Spine. 2002. The effects of neighborhood conditions on perceptions of safety. Journal of Criminal Justice 30(5): 417-427. https://doi. org/10.1016/s0047-2352(02)00148-4

Badiora, A.I., K.O. Popola and O.P. Fadoyin. 2014. Gender differences in risk perception and precautionary behaviour among residents of Nigerian Yoruba Traditional City. International Journal of Ctiminal Justice Sciences 9(1): 143-153. 
Boateng, F.D. and N.S. Adjekum-Boateng. 2017. Differential perceptions of fear of crime among college students: The race factor. Journal of Ethnicity in Criminal Justice 15(2): 138-159. https://doi.org/10.1080/15377938.2017.1310683

Burruss, G., J. Shafer and M. Giblin. 2010. Student perceptions of campus safety initiatives: Assessing views of critical incident prevention \& response. Chicago: Illinois Criminal Justice Information Authority. https://doi.org/10.1037/e586432010-001

Chadee, D., L. Austin and J. Ditton. 2007. The relationship between likelihood and fear of criminal victimization: Evaluating risk sensitivity as a mediating concept. British Journal of Criminology 47(1): 133-153. https://doi.org/10.1093/bjc/azl025

Cops, D. and S. Pleysier. 2011. "Doing gender" in fear of crime: The impact of gender identity on reported levels of fear of crime in adolescents and young adults. British Journal of Criminology 51(1): 58-74. https://doi.org/10.1093/bjc/azq065

Cops, D., S. Pleysier and J. Put. 2012. Worrying about the future and fear of crime among young adults: A social psychological approach. Journal of Youth Studies 15(2): 191-205. https://doi.org/10.1080/13676261.2011.635193

Crowl, J.N. and J.R. Battin. 2016. Fear of crime and the police: Exploring lifestyle and individual determinants among university students. The Police Journal: Theory, Practice and Principles 90(3): 195-214. https://doi. org/10.1177/0032258x16676289

Dobbs, R.R., C.A. Waid and T.O. Shelley. 2009. Explaining fear of crime as fear of rape among college females: An examination of multiple campuses in the United States. International Journal of Social Inquiry 2(2): 105-122.

Doran, B.J. and M.B. Burgess. 2012. Putting fear of crime on the map. London: Springer.

Farrall, S., E. Gray, J. Jackson. 2007. Theorising the fear of crime: The cultural and social significance of insecurities about crime. PhD diss., Keele University. https://doi. org/10.2139/ssrn.1012393

Ferraro, K.F. 1995. Fear of crime: Interpreting victimization risk. Albany: State University of New York Press.

Gainey, R.R. and C.L. Seyfrit. 2001. Fear of crime among rural youth: Testing the generality of urban models to rural areas. Sociological Focus 34(3): 269-286. https://doi.or $\mathrm{g} / 10.1080 / 00380237.2001 .10571199$

Garofalo, J. 1981. The fear of crime: Causes and consequences. Journal of Criminal Law and Criminology 72(2): 839-857. https://doi.org/10.2307/1143018

Grinshteyn, E.G., D.P. Eisenman, W.E. Cunningham, R. Andersen and S.L. Ettner. 2016. Individual-and neighborhood-level determinants of fear of violent crime among adolescents. Family \& Community Health 39(2): 103-112. https://doi. org/10.1097/fch.0000000000000095

Hacin, R. and K. Eman. 2014. Study of the fear of crime in the municipality of Trbovlje using crime mapping tool. Journal of Criminilastic and Criminology 65(4): 299315.

Hair, J.F., R.L. Tatham, R.E. Anderson and W.C. Black. 2010. Multivariate data analysis. 5th ed. Upper Saddle River, NJ: Prentice Hall.

Hale, C. 1996. Fear of crime: A review of the literature. International Review of Victimology 4(2): 79-150. https://doi.org/10.1177/026975809600400201 
Hanslmeir, M., S. Kemme and D. Baier. 2016. Victimisation, fear of crime and life satisfaction. In Representative studies on victimisation: Research findings from Germany, eds. D. Baier and C. Pfeiffer, 251-284. Germany: Nomos. https://doi. org/10.5771/9783845273679-251

Henson, B. and B.W. Reyns. 2015. The only thing we have to fear is fear itself...and crime: The current state of the fear of crime literature and where it should go next. Sociology Compass 9(2):91-103. https://doi.org/10.1111/soc4.12240

Jarrett-luck, M. 2015. Reconceptualising fear of crime: The emergence of crime. PhD diss., Bond University.

Johnson, H. 2005. Crime victimisation in Australia: Key findings of the 2004 international crime victimisation survey. Australian Institue of Criminology 298: 1-6.

Kaplan, R.M. and D.P. Saccuzzo. 1993. Psychological testing: Principles, application, and issues. California: Brooks/Cole Publishing Company.

Lee, M. 2007. Inventing fear of crime: Criminology and the politics of anxiety. UK: Willan.

Lippman, L., S. Burns and E. McArthur. 1996. Urban schools: The challenge of location and poverty. Washington DC: U.S. Department of Education, National Center for Educational Statistics.

Maruthaveeran, S. and C. K. Van den Bosh. 2015. Fear of crime in urban parks: What the residents of Kuala Lumpur have to say? Urban Forestry and Urban Greening 14(3): 702-713. https://doi.org/10.1016/j.ufug.2015.05.012

May, D.C., N.E. Rader and S. Goodrum. 2010. A gendered assessment of the "threat of victimization": Examining gender differences in fear of crime, perceived risk, avoidance, and defensive behaviors. Criminal Justice Review 35(2): 159-82. https://doi.org/10.1177/0734016809349166

Mitchell, M.L. and J.M. Jolley. 2013. Research design explained. Belmont: Wadsworth Cengage Learning.

Mohammad Rahim Kamaluddin, Nadiah Syariani Md. Shariff and Geshina Ayu Mat Saat. 2013. A validity study of Malay translated Zuckerman-Kuhlman personality questionnaire crosscultural 50 items (ZKPQ-50-CC). Health and the Environment Journal 4(2): 37-52.

Mohammad Rahim Kamaluddin, Nadiah Syariani Md Shariff and Geshina Ayu Mat Saat. 2014. Epidemiological profiles of murders and murder victims in Peninsular Malaysia from 2007 to 2011 as reported by a newspaper. IORS Journal of Humanities and Social Science 19(7): 73-81. https://doi.org/10.9790/083719747381

Mohammad Rahim Kamaluddin, Rohany Nasir, Wan Shahrazad Wan Sulaiman, Rozainee Khairudin and Zainah Ahmad Zamani. 2017. Validity and psychometric properties of Malay translated religious orientation scale-revised among Malaysian adult samples. Akademika 87(2): 133-144. https://doi.org/10.17576/akad-2017-870210

Muhammad Amin Bujang, Mohammad Rahim Kamaluddin and Geshina Ayu Mat Saat. 2014. A trend analysis of violent crimes in Malaysia. Health and the Environmental Journal 5(2): 41-56. 
Palmer, C., A. Ziersch, K. Arthurson and F. Baum. 2005. Danger lurks around every corner: Fear of crime and its impact on opportunities for social interaction in stigmatised Australian suburbs. Urban Policy and Research 23: 393-411. https:// doi.org/10.1080/08111470500354216

Pearson, A.L. and G.D. Breetzke. 2013. The association between the fear of crime, and mental and physical wellbeing in New Zealand. Social Indicators Research 119(1): 281-294. https://doi.org/10.1007/s11205-013-0489-2

Rader, N.E. 2004. The threat of victimization: A theoretical reconceptualization of fear of crime. Sociological Spectrum 24(6): 689-704. https://doi. org/10.1080/02732170490467936

Rader, N.E., J.S. Cossman and M. Allison. 2009. Considering the gendered nature of constrained behavior practices among male and female college students. Journal of Contemporary Criminal Justice 25(3): 282-299. https://doi. org/10.1177/1043986209335015

Rader, N.E. and J. Cossman. 2011. Gender differences in US college students' fear for others. Sex Roles 64(1): 568-581. https://doi.org/10.1007/s11199-011-9940-5

Ratnayake, R. 2016. Association between fear of crime gender, student nationality and physical features. Environment and Behavior 1-16. https://doi. org/10.1177/0013916516644875

Scarborough, B., T. Like-Haislip, K. Novak, W. Lucas and L. Alarid. 2010. Assessing the relationship between individual characteristics, neighbourhood context, and fear of crime. Journal of Criminal Justice 38(1): 819-826. https://doi.org/10.1016/j. jcrimjus.2010.05.010

Siti Rasidah Md Sakip, Aldrin Abdullah and Mohd Najib Mohd Salleh. 2013. Fear of crime in residential areas. Asian Journal of Environmental-Behaviour Studies 4(11): 27-38. https://doi.org/10.21834/aje-bs.v3i7.261

Snedker, K.A. 2006. Altruistic and vicarious fear of crime: Fear for others and gendered social roles. Sociological Forum 21(2): 163-195. https://doi.org/10.1007/s11206006-9019-1

Sutton, R.M. and S. Farrall. 2005. Gender, socially desirable responding on the fear of crime: Are women really more anxious about crime? The British Journal of Criminology 45(2): 212-224. https://doi.org/10.1093/bjc/azh084

Syerrina Zakaria and Nuzlinda Abdul Rahman. 2016. The mapping of spatial patterns of property crime in Malaysia: Normal mixture model approach. Journal of Business and Social Development 4(1): 1-11.

Tomsich, E.A., A.R. Gover and G. Jennings. 2011. Examining the role of gender in the prevalence of campus victimization, perceptions of fear and risk of crime, and the use of constrained behaviors among college students attending a large urban university. Journal of Criminal Justice Education 22(2): 181-202. https://doi.org /10.1080/10511253.2010.517772

Unit Pengurusan Prestasi dan Pelaksanaan (PEMANDU). 2015. Laporan tahunan program transformasi negara 2015. Putrajaya: PEMANDU, Jabatan Perdana Menteri.

Vauclair, C.M. and B. Bratanova. 2017. Income inequality and fear of crime across the European region. European Journal of Criminology 14(2): 221-241. https://doi. org/10.1177/1477370816648993 
Wilcox, P., C.E. Jordan and A.J. Pritchard. 2006. Fear of acquaintance versus stranger rape as a "master status": Towards refinement of the "shadow of sexual assault." Violence \& Victims 21(3): 355-370. https://doi.org/10.1891/088667006780644631

Will, J. 1995. Crime, neighborhood perceptions, and the underclass: The relationship between fear of crime and class position. Journal of Criminal Justice 23(2): 163176. https://doi.org/10.1016/0047-2352(95)00004-a

Yarwood, R. and G. Gardner. 2000. Fear of crime, cultural threat and the countryside. Area 32(4): 403-411. https://doi.org/10.1111/j.1475-4762.2000.tb00156.x

Yirmibesoglu, F. and N. Ergun. 2015. Fear of crime among women in the old city center of İstanbul. Current Urban Studies 3(2): 161-174. https://doi.org/10.4236/ cus. 2015.32014

Zarafonitou, C. 2008. Fear of crime and victimisation: The Greek experience. In Fear of crime-punitivity: New developments in theory and research ed. H. Kury, 159172. Bochum: Brockmeyer Verlag.

Zuckerman, D.J. 2010. Student perceptions of campus safety: How the university community may make a difference. $\mathrm{PhD}$ diss., Fordham University, Amerika Syarikat. 